\title{
ULUSLARARASI SERMAYE AKIMLARININ KONTROLÜ VE AVRUPA BİRLIGĞI'NIN KONUYA YAKLAŞIMI HAKKINDA BİR INCELEME
}

\section{Arif Orçun SÖYLEMEZ* Server DEMIRC $\dot{I}^{* *}$}

\section{$\ddot{O}_{z e t}$}

1973'te Amerika Birleşik Devletleri, Almanya, Kanada, Isviçre ve Hollanda, 1979'da ise Ingiltere ve Japonya sermaye hesaplart üzerindeki kontrolleri kaldırmıştır. Böylece 1970'ler boyunca ilk olarak gelişmiş ekonomilerde bir finansal serbestleştirme hareketi ortaya çıkmıştır. Söz konusu finansal serbestleştirme hareketlerine, yurtiçi yatırımlarl için diş finansman sağlayabilmek ümidiyle 1980'li yıllarda Türkiye, Meksika, Arjantin, Endonezya, Tayland, Malezya gibi gelişmekte olan ülkeler de dahil olmuştur. Neticede son kırk yılda birçok ülke uluslararası sermayenin hareketliliğini engelleyebilecek düzenlemeleri ortadan kaldırmıştır. Bu süreçte IMF ve Dünya Bankası gibi uluslararası örgütlerin yakın geçmişe değin uluslararası sermaye hareketliliğinin artırllması gerektiği yönünde bir uzlaşlya sahip olduğu bilinmektedir. Teorik olarak ise iktisat literatüründe uluslararast sermayeye tam serbesti sağlanmast gerektiğini savunan fikirler yanında kontrolü savunan yaklaşımlar da öteden beri mevcuttur. 2008 yllında yaşanan ve Amerika ile Euro Alanı gibi gelişmiş ekonomik merkezleri vuran küresel finansal çöküşün ardından, IMF ve Dünya Bankasl gibi uluslararası örgütler de dahil olmak üzere, artık tam serbestiyi destekleyenlerin sayısı giderek azalmış ve bazı hallerde uluslararası sermayenin kontrolünün daha iyi sonuçlar verebileceği düşüncesi hakim düşünce haline gelmiştir. Bu bağlamda benzer bir düşünsel yönelim Avrupa Birliği'nde de ortaya çıkmış ve çeşitli uygulamalar hayata geçirilmiştir. Bu makale sermaye hareketleri hakkındaki literatür ile sermaye kontrolüne iliş̧kin çeşitli yöntemleri özetlemekte ve Avrupa Birliği'ndeki sermaye kontrolü tartışmaları ile uygulamaların incelemektedir.

Anahtar Kelimeler: Uluslararası sermaye akımlarl, McKinnon-Shaw hipotezi, piyasa yanlışlarl, Tobin vergisi

\footnotetext{
*Yrd. Doç. Dr., Marmara Üniversitesi, İktisat Fakültesi, İngilizce İktisat Bölümü, orcun.soylemez@marmara.edu.tr

**Yrd. Doç. Dr., Marmara Üniversitesi, Bankacılık ve Sigortacılık Yüksek Okulu, server_demirci@yahoo.com
} 


\section{A SURVEY ON THE CONTROL OF INTERNATIONAL CAPITAL FLOWS AND THE EUROPEAN UNION'S PERSPECTIVE ON THE ISSUE}

\section{Abstract}

In 1973, the United States of America, Germany, Canada, Switzerland and Holland and then, in 1979, Japan and England abolished the controls on their capital accounts. Thus, a financial liberalization movement emerged initially in the developed countries. Developing countries such as Turkey, Mexico, Argentina, Indonesia, Thailand, Malaysia joined the financial liberalization movement in 1980s hoping to raise external capital for the domestic investments. In the end, numerous countries discarded in the last forty years the regulations that could hinder the mobility of international capital. It is known that international organizations such as IMF and the World Bank had a consensus view on the need for increasing the mobility of international capital until recent past. However, from a theoretical standpoint, views for managing international capital flows always existed in the economics literature along with the views advocating perfect capital mobility. In the aftermath of the global financial collapse which hit the advanced economic centers such as the United States and the Euro Area in 2008, number of the advocates of perfect capital mobility - including the IMF and the World Bank decreased and the view that management of capital flows might result in better ends became the dominanting view. In this context, a similar intellectual tendency emerged in the European Union and some practices came into effect. This article summarizes the literature on capital movements along with various methods of capital controls and reviews the discussions and implementations within the European Union regarding the capital controls.

Keywords: International capital flows, McKinnon-Shaw hypothesis, market failures, Tobin tax

\section{Giriş}

14 Kasım 2012 tarihinde Uluslararası Para Fonu (IMF), uluslararası sermaye akımlarına ilişsin olarak yeni bir kurumsal yaklaşım benimsediğini dünyaya ilan etmiştir. ${ }^{1}$ Söz konusu yeni yaklaşımın temellerini kısaca altı noktada ortaya koymak mümkündür. Öncelikle IMF, aynı eskiden de olduğu gibi, serbest uluslararası sermaye akımlarının ülkelere genel anlamda yarar getirdiğini düşünmektedir. Ancak eski çizgisinden farklı olarak IMF, serbest sermaye akımlarının ülkeler için riskler de taşıdığını artık kabul etmektedir. Üçüncü olarak, serbest uluslararası sermayenin belirli bir finansal ve ekonomik gelişmişlik düzeyine erişmiş ülkeler için daha az riskliliğe sahip olduğunu ve daha fazla yarar sağlayabildiğini iddia

\footnotetext{
${ }^{1}$ International Monetary Fund, 14 Kasim 2012.
} 
eden IMF, dördüncü bir husus olarak ise ülkelerin sermaye hesaplarında serbestliğe tedrici politikalarla hazırlanması (bu anlamda da soğuk hindi tabir edilen şok politika değişikliklerinden kaçınılması) gerektiğini ifade etmektedir. Beşinci olarak, sermaye çeken ülkeler kadar sermaye gönderen büyük ülkelerin de küresel finansal sistemin istikrarını gözetmesi gerektiğini belirten IMF, son olarak ise serbest sermaye akımlarının kontrolüne ilişkin olarak ülkelere tavsiye ve yardımda bulunabileceğini ifade etmektedir.

IMF gibi Dünya Bankası da 2008 yılında ortaya çıkan küresel ekonomik çöküşün ardından uluslararası sermaye hareketlerinin tamamen serbest bırakılmasına şüphe ile yaklaşmaktadır. Örneğin Dünya Bankası 2008 sonrası dönemde Amerika Birleşik Devletleri (ABD)'nce izlenen genişleyici para politikasının sıcak para hareketleri olarak ortaya çıkabilecek potansiyel olumsuz etkilerinden sakınabilmeleri amaciyla Asya ülkelerine sermaye kontrolleri uygulamayı önermiştir. ${ }^{2}$ IMF ve Dünya Bankası gibi 2008 öncesi dönemde Washington Uzlaşısı olarak anılan neoliberal uluslararası iktisat politikalarının destekçisi kurumların yanında artık dünyanın önde gelen ekonomileri de sermaye kontrollerine daha sıcak bakmaktadır. Kasım 2011'de G-20 ülkeler grubu tarafından belirlenen ve serbest bırakılmış uluslararası sermayenin hem yararları hem de riskleri olduğunu kabul eden ilkeler bu gerçeğe işaret etmektedir. ${ }^{3}$

Açıkça görüldüğü üzere serbest sermaye akımları hususunda dünyada önemli görüş değişiklikleri ortaya çıkmaktadır. 1990'lı yıllar boyunca tam serbestliği savunulan uluslararası sermayenin artık gerekirse kontrol edilebileceği belirtilmektedir. Bu fikri değişimin arka planında 2008 yılında ABD ve Euro Alanı ülkeleri gibi gelişmiş ekonomilerin finansal sorunlara sürüklenmiş olması yatmaktadır. Nitekim bu sayede finansal sistemin içsel (kendiliğinden ortaya çıkan) istikrarsızlıklara sahip olduğu düşüncesi yayılmış, gelişmiş ekonomilerin bile bu istikrarsızlıkların kurbanı olabileceği görülmüş ve neticede finansal istikrar kavramı öne çıkmıştır. Bugün finansal istikrarın bir amaç olarak Türkiye Cumhuriyet Merkez Bankası (TCMB) tarafindan da hedeflendiği bilinmektedir. TCMB finansal istikrar amacına yönelik olarak faizlerin düşük tutulması, bu sayede kısa vadeli getiri peşinde koşan uluslararası sermayenin Türkiye'ye yöneliminde kontrollü bir azalma sağlanması üzerine politikalar geliştirmektedir.

2008 sonrası dönemde Euro Alanı'ndaki finansal sorunlarla boğuşmak durumunda kalan Avrupa Birliği'nde de sermaye kontrolleri üzerinde sicak tartışmaların yapıldığı bir konudur. Dünyada sermaye hareketlerinin kontrol edilmesinin gerekliliği üzerine fikirlerin ortaya atıldığ 1 ve para otoritelerince finansal istikrar hedefleri uyarınca uluslararası sermaye hareketliliğini kısıtlayıcı

\footnotetext{
${ }^{2}$ Bloomberg, 9 Kasim 2010.

${ }^{3}$ G-20, 15 Ekim 2011.
} 
politikaların oluşturmaya çalışıldığı bir dönemde bu makale sermaye hareketleri ve ne tür yöntemlerle kontrol edilebilecekleri üzerine kapsamlı bir inceleme olması amacıyla yazılmıştır. Yazının devamı sırasıyla şu bölümlerden oluşmaktadır. İkinci bölümde uluslararası sermaye hareketlerinin serbestleşmesi dönemi kısaca özetlenmektedir. Üçüncü bölümde serbest sermaye hareketleri üzerine ortaya çıkmış bulunan teorik yaklaşımlar ele alınmaktadır. Dördüncü bölümde serbest sermayenin kontrolü yöntemlerinden bahsedilmekte ve AB'de konuya ilişkin olarak ortaya atılan fikirler ve uygulamaya konulmuş bulanan politikalar özetlenmektedir. Beşinci bölümde sonuçlar tartışılmaktadır.

\section{Uluslararası Finansal Serbestleştirmenin Geçmişi}

1973'te öncelikle Amerika Birleşik Devletleri (ABD), Almanya, Kanada, İsviçre ve Hollanda, 1979 'da ise İngiltere ve Japonya sermaye hesapları üzerindeki kontrolleri kaldırmıştır. Böylece 1970'ler boyunca ilk olarak gelişmiş ekonomilerde bir finansal serbestleşme hareketi ortaya çıkmıştır. Söz konusu finansal serbestleşme hareketlerine, yurtiçi yatırımlar için dış finansman sağlayabilmek ümidiyle 1980'li yıllarda Türkiye, Meksika, Arjantin, Endonezya, Tayland, Malezya gibi gelişmekte olan ülkeler de dahil olmuştur. Ancak, birçok gelişmekte olan ülke; yüksek kamu açıklarının olduğu, fiyat istikrarının sağlanmadığı ve finansal piyasaların denetimini sağlayacak etkin kurumların oluşturulmadığı bir ortamda finansal serbestliğe geçmiştir.

Gelişmekte olan ülkelere yönelik sermaye hareketlerinin niteliği zaman içinde büyük ölçüde farklılık göstermiştir. 1980'lerde ulusal ekonomilerin tasarruf-yatırım dengesizlikleri sebebiyle ortaya çıkan finansman ihtiyacını karşılama işlevini yüklenen sermaye hareketleri, özellikle 1990'larda büyük oranda arbitraj kazancına yönelik spekülatif nitelikli para hareketlerine dönüşmüş ve bu değişime paralel olarak da sermaye hareketlerinin vadesi kısalmış, oynaklığı artmıştır. Sözkonusu dönemdeki sermaye hareketlerinin bir diğer özelliği ise, ülkelerin resmi kanallardan borçlanmak yerine uluslararası piyasalardan borçlanmaya yönelmiş olmasıdır. $\mathrm{Bu}$ niteliksel değişimler sermaye akımlarının kompozisyonunu da etkilemiş, gelişmekte olan ülkelere yönelik sermaye akımları içinde kısa vadeli sermaye ve portföy yatırımlarının payı hızla artmıştır.

Özellikle 1990’lı yıllarda birçok kez sermaye hareketlerine dayalı uluslararası finansal krizlerin yaşanması nedeniyle kısa vadeli sermaye hareketleri hem akademik hem de politik çevrelerde yoğun biçimde tartışılan bir konu haline gelmiştir. Ekonomi teorisi, sermaye hareketlerinin tamamen serbest birakılip bırakılmaması üzerinde tam bir görüşbirliği sağlayabilmiş değildir. Teorik altyapısını McKinnon ve Shaw'un çalışmalarının oluşturduğu "Ortodoks İktisadi Yaklaşımlara" göre, sermaye hareketlerinin tamamen serbest bırakılması önerilmektedir. Ekonomik birimlerin rasyonel davrandığı varsayımına itiraz eden 
ya da rekabetçi fiyat-miktar çözümlerinin verimli olamayacağını savunan farklı yaklaşımlara göre ise sermaye hareketlerinin kontrol altında tutulması gerekmektedir.

Global sermaye hareketlerinin kontrol altına alınmasına yönelik olarak kurulacak kontrol sistemlerinin çeşitleri, kapsamları ve süreleri hakkında da yoğun tartışmalar devam etmektedir. Teorik alanda en yoğun biçimde tartışılan önerilerden birisi James Tobin tarafından 1972 yılında gündeme getirilen "Tobin Vergisi"dir. Dünya genelinde uygulanması önerilen verginin teorik boyutta öne sürdügü faydalar, Şili ve Malezya gibi ülke uygulamalarından da görüldüğü üzere ulusal çapta uygulanabilecek çeşitli politikalarla da sağlanabilmektedir.

Tablo 1: Serbest Sermaye Akımlarının Öngörülen Yararları

\begin{tabular}{|c|c|}
\hline Makroekonomik Yararlar & Mikroekonomik Yararlar \\
\hline 1. Tasarruf Açı̆̆ı Olan Ülkelerde & 1. Tasarruf Açı̆̆ \\
\hline Sermaye Girişi & Büyümeye Paralel Refah Artışı \\
\hline Artan Yatırımlar & Sermayenin En Verimli Projelere Akması \\
\hline \multirow{2}{*}{\multicolumn{2}{|c|}{$\begin{array}{l}\text { EkonomikBüyüme } \\
\text { Cari Açŏın Finansmanında Kolavlık }\end{array}$}} \\
\hline & \\
\hline 2. Dünya Genelinde & 2. Yatırımcı Açısından \\
\hline Birbirine Yakınsayan Faiz Oranları & Daha İyi Portföy Çeşitlendirmesi \\
\hline
\end{tabular}

Kaynak: Karataş ve Söylemez (2005:5).

\section{Teorik Yaklaşımlar}

Sermaye hareketlerinin serbestleştirilmesi üzerine teorik düzeyde "Eski Ortodoks İktisadi Yaklaşımlar", "Tarihi ve Psikolojik Yaklaşımlar" ve "Piyasa Yanlışlarını Dikkate Alan Yaklaşımlar" olmak üzere üç farklı yaklaşım bulunmaktadır (Karataş ve Söylemez, 2005: 5). Ortodoks iktisadi yaklaşımlar sermaye hareketlerinin tamamen serbest birakılmasını önermektedir. Ekonomik ajanların akılcılığı varsayımına itiraz eden tarihi ve psikolojik yaklaşımlar ile finansal piyasalarda çeşitli piyasa yanlışları sebebiyle rekabetçi fiyat-miktar çözümlerinin verimli olamayacağını savunarak piyasa yanlışlarını ele alan yaklaşımlara göre ise sermaye hareketlerinin kontrol altında tutulması gerekli görülmektedir.

\subsection{Eski Ortodoks İktisadi Yaklaşımlar}

Sermaye hareketlerinin serbestleştirilmesinin teorik temelini, 1973 y1lında Shaw ve McKinnon'un ayrı ayrı ortaya koyduğu, finansal baskı (financial repression) adı 
ile anılan yaklaşım oluşturmaktadır. ${ }^{4}$ Shaw ve McKinnon, ülkelerde uygulanan finansal baskı politikalarının negatif reel faiz oranlarına neden olmasının yurtiçi tasarruf oranlarının düşük kalmasına ve dolayısıyla yatırımlara yönelecek fonlarda azalmaya sebep olduğunu, bu durumun da kaynak dağılımında etkinlik kaybına yol açtığını belirtmişlerdir. Ülkelerin sermaye hareketlerini serbestleştirmeleri durumunda, sermayenin getirinin düşük olduğu sermaye yoğun ülkelerden getirinin daha yüksek olduğu ülkelere doğru akacağını ve ülkeler arasındaki faiz oranlarının eşitlenme eğilimine gireceğini varsaymışlardır. Ayrıca, sermayenin girdiği ülkelerde yatırımların, büyümenin ve toplumsal refahın artacağını öngörmüşlerdir.

2008 yılındaki ekonomik krize değin ana akım iktisadi yaklaşımın temelini oluşturmuş bulunan eski ortodoks iktisadi yaklaşımlara göre; serbest hareket eden sermayenin tüm dünyada en verimli projelerin finansmanına kanalize olacağ1, ülkelerin cari açıkları sebebiyle karşılaştıkları ödemeler dengesi krizlerinin engellenmesine yardımcı olacağı ve yatırımcılar için daha iyi bir portföy çeşitlendirme imkânı sunacağı öngörülmektedir (Karataş ve Söylemez, 2005: 5).

\subsection{Tarihi ve Psikolojik Yaklaşımlar}

Finansal krizleri tarihi ve psikolojik perspektiften değerlendiren "tarihi ve psikolojik yaklaşımlara" göre son iki yüzyıl içinde yaşanan uluslararası borç krizlerinin hepsinde ortak noktalar mevcuttur. Herhangi bir nedenle dünya finans merkezlerinde likidite artışının yaşanması, bu merkezlerde işlem yapan yatırımcıların gelişmekte olan piyasalara borç vermesini hızlandırmakta, ancak bu durum kısa bir süre içinde sadece kendi kendini besleyen bir süreç halini almaktadır. Yatırımcılara kısmi akılcılık atfeden yaklaşımlara göre, bu tip bir süreçte yatırımcılar temelsiz bir güven duygusuyla hareket ederek gelişmekte olan piyasalara aşırı miktarda kaynak aktarabilmekte ancak, bir nedenle bu olumlu havanın tersine dönmesiyle de aşırı tedirginliğe kapılabilmektedirler. Bu süreçte, yatırımcı davranışları akılcı insan davranışı özelliği göstermemektedir. Sonuç olarak, belirli bir dönemde sürü psikolojisi ile hareket ederek kaynak aktaran yatırımcılar yine sürü psikolojisiyle kaynaklarını geri çekebilmektedirler. $\mathrm{Bu}$ durum, aşırı borçlanan ülkelerin ciddi bir borç sorunuyla karşılaşmalarına ve krize neden olmaktadir.

Tarihi perspektiften bakıldığında global sermaye hareketlerine bağlı ilk uluslararası krizin 1825 yılında yaşandığ 1 , 1830'da benzer bir bunalımın ardından 1873 ve 1890 'ların da ciddi kriz dönemleri olduğu görülmektedir. 20. yüzyılın önemli kriz dönemleri ise 1930 buhranı ve 1980'lerin başındaki borç krizi yıllarıdır. 21. yüzyıl ise 2008 sonunda ABD ve Euro Alanı'nda başgösteren finansal sorunlarla başlamıştır. Tarihi perspektiften bakıldığında arada sırada ortaya çıkan

\footnotetext{
${ }^{4}$ McKinnon (1973) ve Shaw (1973).
} 
bu tür finansal sorunların düşük frekanslı bir tarihi çevrimin (cycle) bir parçaları olduğu düşünülmektedir (Karataş ve Söylemez, 2005: 6).

\subsection{Piyasa Yanlışlarını Dikkate Alan Yaklaşımlar}

Sermaye hareketlerinin serbest bırakılmasına karşı çıkan diğer bazı yaklaşımlar ise yatırımcıların akılcılığı konusunda bir eleştiri yapmamakta, ancak çeşitli piyasa yanlışları üzerinde durarak sermayenin kontrol edilmesinin gerekliliğini ifade etmektedir. Piyasa yanlışlarının olduğu bir ortamda serbest işleyen piyasalar kendilerinden beklenen en iyi iktisadi çözümü gerçekleştirememektedir. $\mathrm{Bu}$ durumda piyasalara yerinde müdahalelerle daha etkin piyasa çözümlerinin sağlanması imkânı vardır. En iyi çözümün piyasa mekanizması tarafından gerçekleştirilemediği hallerde en iyi ikinci çözümün aranmasını vurgulayan bu tür yaklaşımların özellikle üzerinde durduğu piyasa yanlışları arasında bilginin asimetrik dağılımından ${ }^{5}$ kaynaklanan aksaklıklar ve eksik piyasalar (dışsallıklar) ${ }^{6}$ öne çıkmaktadır.

En iyi iktisadi çözüm; piyasa tarafından gerçekleştirilecek bir miktar-fiyat çözümüdür. Oysa piyasa yanlışları altında işleyen global finans sisteminde, sermaye hareketlerinin serbest olmasıyla birlikte aşırı bir borç verme (ve aşırı borç alma) olgusu ortaya çıkmaktadır. Bank for International Settlements (BIS) verilerine göre 2010 yılında türev ürünler de dahil edildiğinde global döviz piyasasında günlük işlem hacmi $\$ 4.0$ trilyondur. 220 işgünü baz alınarak hesaplandığında $\$ 880$ trilyona ulaşan yıllık işlem hacmi, Dünya Ticaret Örgütü'nün 2010 yılı verilerine göre yıllık $\$ 15.2$ trilyon olan global ticaret hacminin finansman ihtiyacının çok ötesinde bulunmaktadır. Yüksek miktardaki global likidite, her zaman fonlayabileceği kadar çok verimli projeler bulamamaktadır. Bu durumda da artan sermaye akımlarına bağlı olarak yurtiçi piyasalarda fiyatlama yanlışları ortaya çıkmakta ve temelsiz bir biçimde gayrimenkul piyasalarında ve borsalarda balon tabir edilen aşırı fiyat artışları yaşanabilmektedir. Miktar ve fiyatlarda oluşan aşırılıkların temelinde piyasa yanlışlarının olduğunu savunan yaklaşımlar da sermaye hareketlerinin sınırlandırılmasını önermektedir (Karataş ve Söylemez, 2005: 7). ${ }^{7}$

Aslında serbest piyasa temelli uluslararası finansal sistem Rogoff ve Obstfeld'in (2001) gösterdiği üzere bilgi asimetrileri, dişsallıklar vb. nedenlerle oluşan piyasa yanlışlarının yanında işlem maliyetleri gibi piyasa aksaklıklarından ötürü de iktisadi verimsiz miktar-fiyat çözümleri yapabilmektedir. Uluslararası finansal sistemin

\footnotetext{
${ }^{5}$ Piyasada tarafların tam bilgiye sahip olmadıkları, bir tarafin diğer taraftan daha fazla bilgiye sahip olduğu durumu ifade etmektedir.

${ }^{6}$ Dışsallık, mal ve hizmetlerin optimuma göre daha az veya daha fazla arzına neden olan bir piyasa yanlışıdır.

${ }_{7}^{7}$ Piyasa yanlışlarının uluslararası sermaye akımları ve finansal sisteme etkileri hakkında detaylı bir çalışma için bkz. Söylemez (2004).
} 
sorunlarını teorik olarak tam bir biçimde ifade etmek için ise aslında piyasa yanlışları (market failures) ve piyasa aksaklıkları (market imperfections) yanında piyasa eksikliği (market incompleteness) kavramından da bahsedilmesi gerekir (Söylemez, 2003). Nihayetinde, piyasa yanlışları, aksaklıkları ve eksikliği de göz önüne alındığında sermaye hareketliliğinin kontrolü noktasında kuvvetli argümanlar oluşturulabilmektedir.

\section{Dünyada Sermaye Hareketlerine Dayalı Krizlerin Önlenmesi İçin Çözüm Önerileri}

Tarihi olarak sermaye hareketlerine dayalı olarak ortaya çıkma riski bulunan krizlerin önlenmesi için üretilmiş çözüm önerileri; vergi veya vergi benzeri araçların kullanımını öneren çözümler ile yasa koyucu ya da mali sektörü düzenleyici-denetleyici kurumların yapacağı direkt kontrolleri (doğrudan düzenlemeler) öneren çözümler olarak iki grupta toplanabilir.

Ancak şu gerçek de not edilmelidir ki, 2008 küresel bunalımının ardından finansal istikrar sağlama amacıyla merkez bankalarının da para politikası araçlarını daha aktif olarak kullanarak sermaye hareketlerinden kaynaklanan istikrarsızlıkları hedef almaya başladıkları görülmektedir.

\subsection{Direkt Kontroller}

Günümüzde direkt kontroller serbest piyasa ekonomisi mantığına ters olduğu için tercih edilmemektedir. Bu tip düzenlemeler her zaman için çeşitli yöntemlerle etkisiz k1lınabilir. Bu nedenle istenilen verimi elde etmek zordur. Ancak, 1998 yılında Güneydoğu Asya'da patlak veren krizde Malezya hükümeti bu tip direkt kontroller uygulayarak ülkeden yabancı para çıkışına belirli bir süre izin vermemiştir. Bu politika doğrultusunda dış borçlarını ödemek için kaynak bulmak zorunluluğundan kurtulan hükümet, IMF gibi kreditör kuruluşlardan yardım almak zorunda kalmamıştır. Ancak, Malezya'da sermaye yatırımlarının içinde doğrudan yatırımların ağırlığının yüksek olmasına karşın, dış finansman ihtiyacının önemli kısmını portföy yatırımları ile karşılayan Türkiye'nin kriz dönemlerinde benzer kontroller uygulamasının kriz sonrası dönemde oldukça yüksek maliyetle borçlanmayı da beraberinde getireceği açıktır (Karataş ve Söylemez, 2005: 14).

\subsection{Vergi veya Vergi Benzeri Araçlarla Sağlanan Kontroller}

Vergi veya vergi benzeri araçlarla kısa vadeli sermaye giriş çıkışlarının maliyetinin arttırılmasını ve böylece sermayenin hareketliliğinin bir miktar azaltılmasını öngören yaklaşımlar ise dolaylı kontroller arasında sayılmaktadır. $\mathrm{Bu}$ tip araçların en ünlüsü Yale Üniversitesi profesörlerinden James Tobin'in 1972 yılında önerdiği, döviz işlemleri üzerine uygulanacak bir ad-valorem (oransal) vergi 
olan "Tobin Vergisi"dir. ${ }^{8}$ Barry Eichengreen ve Charles Wyplosz tarafindan önerilen bir başka vergi ise, sermayenin ülkeden çıkarken vergilendirilmesini ve bu sayede cari işlemler açığı yüksek ülkelerin ödemeler dengesi problemleri ile karşılaşma riskinin azaltılmasını savunmaktadır. Politika yapıcı kurumların ve merkez bankalarının yaptığı çeşitli önerilere bakıldığında ulusal düzeyde uygulanmış ve çeşitli ölçülerde başarı da sağlamış politika araçlarına rastlanmaktadır.

$\mathrm{Bu}$ tür araçlardan en önemlisi, vergi benzeri etkide bulunan ve sermayenin bir ülkeden diğerine geçişinin maliyetini artıran düzenlemelerdir. En iyi bilinen ve üzerinde en çok konuşulan örneği Şili'de uygulanan munzam karşl1ık ayırma zorunluluğu olan bu tür araçların, uygulandıkları ülkelerde zaman içinde kısa vadeli sermaye hareketleri ile daha istikrarlı olan doğrudan yatırımlar arasında bir ayırıma yol açtıkları görülmektedir. Böylece, kısa vadeli sermaye girişlerinin payı giderek azalmış ve kısa vadeli sermaye hareketlerinin yarattığ etkilenmediği için ekonomik istikrarın görece korunabilmesi mümkün olmuş, doğrudan yatırımların payı artmıştır. Ancak, Brezilya'da 1992-1994 dönemindeki benzer uygulamaların başarı sağlayamadığı görülmüştür. Yine de belirtilmelidir ki Brezilya Ekim 2009 yılından bu yana yabancı ülkelerden Brezilya'ya yönelen portföy yatırımlarına \%2 oranında vergi uygulaması başlatmış bulunmaktadır. Ayrıca, 1994'de Türkiye'de de Merkez Bankası'nın bankacılık sektörünün kullandığı döviz kredilerini munzam karşılığa tabi tutmasına ve bir yıldan kısa vadeli kredilere Kaynak Kullanımını Destekleme Fonu (KKDF) adıyla ek vergi uygulamış olmasına rağmen istenen sonuç elde edilememiştir. Bu süreçte krediler üzerindeki ek maliyetler bankacılık sektörünün ödeyeceği faizlere yansırken, kredilerin bir yılın biraz üzerinde bir süre için alınmasıyla KKDF maliyetinden kaçınmak mümkün olmuştur.

Ülkelerin sermaye hesaplarının tam bir serbestliğe sahip olmasını eleştiren görüşlere göre; gelişmekte olan piyasalar henüz serbest sermaye hareketlerinden istenilen yararları sağlayacak durumda değildirler. Birçok gelişmekte olan ülkede, bankacılık sektörünün ve reel sektörün aldığı yüksek düzeylere ulaşan borçlar krizlere girilmesinde önemli bir rol oynamaktadır. Genelde sabit kur sistemine geçilerek bir istikrar programının uygulanmaya başlandığ 1 dönemlerde, istikrar programı dolayısıyla kamu maliyesinde disiplin sağlanmakta ve sabit kur sistemi sebebiyle kur riskinin ortadan kalkması gibi yatırımcıya güven verici gelişmeler ortaya çıkmaktadır. Bu durumda, yabancı yatırımcılar gelişmekte olan piyasalara yatırım yapmaya istekli hale gelebilmektedir. Ancak, bu süreçte uygun koşullarda yüksek miktarda borçlanan bankacılık ve reel sektör kesimleri, sabit kur sistemi üzerinde baskı oluşturmaktadır. Sermaye akımlarına paralel olarak değerlenme

\footnotetext{
${ }^{8}$ Tobin (1978).
} 
eğilimine giren ulusal para sebebiyle sabit kur sisteminin bozulmamasını isteyen merkez bankaları, döviz piyasalarına döviz alımı yaparak müdahalede bulunmaktadır. Merkez bankalarının döviz rezervlerinin arttı̆̆ bu süreçte, giren kaynaklar verimli yatırımların finansmanından ziyade merkez bankası rezervlerinin artırılması için kullanılmaktadır. Asya ve Latin Amerika ülkeleri ile Türkiye örneklerinde de görüldüğü gibi bir noktada sabit kurun devam ettirilemeyeceğini düşünen yatırımcılar paralarını ülkeden çıkarma telaşına kapılmakta, aniden azalan döviz likiditesi sebebiyle ulusal para aşırı değer yitirmekte ve döviz cinsi yükümlülükler ödenemez duruma gelmektedir. $\mathrm{Bu}$ durumda, gelişmekte olan piyasalarda bir dizi değişim gerçekleşmeden krizlerden kaçınmanın mümkün olamayacağını ileri sürenlere göre gelişmekte olan piyasalarda bankacılık sektörünün risk yönetimine ağırlık vermesi ve sermaye yeterlilik oranlarının dikkatle izlenmesi önerilmektedir. Kurumların, şartlar uygun olsa bile riske maruz değerlerinde aşırıya kaçmaması için, şeffaf yönetilmeye ve en küçük hissedara karşı bile maksimum sorumlulukla hareket etmeye azami önem vermesi gerekmektedir.

Makroekonomik düzeyde ise sabit kur rejimi yerine dalgalanmaya bırakılmış kur rejimi önerilmektedir. Ayrıca yatırımcıların tedirginliklerinin azaltılması için siyasi olarak da hükümetlerin sorumlu davranması gerektiği belirtilmektedir. 1998 yılında Güneydoğu Asya krizinden sonra Endonezya'ya dalgalı kur rejimi önerisi yapan IMF, benzer politika önerisini 2001'de Türkiye'ye de yapmıştır. Ayrıca bankacılık sektörünün kuvvetlendirilmesi çalışmaları yapısal reform şartları arasında yer almıştır. Aynı dönemde Uluslararası Finans Kurumu (IFC) ve Ekonomik İşbirliği ve Kalkınma Örgütü (OECD)'nün kurumsal yönetişim ilkeleri olarak adlandırılan ve şirket yönetiminde şeffaflı̆̆ı esas alan OECD ilkelerinin ön plana çıktığı görülmektedir (Karataş ve Söylemez, 2005: 14-15).

Ghosh ve diğerleri (2012, s:17) gelişmekte olan ülkelere yönelik sermaye hareketlerinde yaşanan artışları yurtiçi piyasalardaki gelişmelerden daha ziyade yurtdışı piyasalardaki gelişmelerin ve bilhassa ABD'deki likidite koşulları ve yatırımcıların risk alma iştahının belirlediğini bildirmektedir. Söylemez ve Demirci (2013) ise Türkiye'ye yönelik sermaye akımları ile Türk ekonomisinin büyümesi arasındaki ilişki üzerine yazdıkları bir makalelerinde, Türk ekonomisinin hızlı büyümesinin yabancı sermaye açısından bir çekim etkisi yaratmadığını ortaya koymaktadır. Başka bir ifadeyle sermaye akımlarının devamlılığı veya artışı azalışı her zaman için gelişmekte olan ülkelerin kendi iç koşulları ile kontrol edebilecekleri birşey değildir. $\mathrm{Bu}$ durumda, verimliliği ülke içi ya da dışı gelişmelere bağlı olmayan Tobin Vergisi gibi öneriler daima gündemde kalmaktadır. 


\subsubsection{Tobin Vergisi}

\subsubsection{Teorik Temeli}

Tobin Vergisi; ekonomideki dışsallıkların neden olduğu aşırı üretimi sinırlandırma amacina hizmet eden ve toplumun eksik piyasalar nedeniyle yüklenmiş olduğu maliyetin fiyatlandırmasını yaparak eksik piyasayı vergi otoritesi tarafından tamamlamayı öngören düzenleyici bir vergidir. Bilinen örnekle, bir nehir kıyısında üretim yapan ve bu üretimi nedeniyle nehri kirleten bir işletmenin var olduğunu ve bu kirlenmeden olumsuz etkilenen kasaba halkının da nehrin aşağ kısmında yaşadığını varsayalım. Aslında işletme, faaliyeti dolayısıyla toplumsal bir maliyete yol açmaktadır. Ancak, piyasalar eksik olduğu için bu maliyetin karşılığını kasaba halkına ödememektedir. Başka bir deyişle suyu kirletilen kasaba halkına tazminat ödemesi gereken işletme, kendisinden bu paranın talep edilebileceği bir piyasanın olmadığı durumda hiçbir maliyete katlanmadan üretimine devam edecektir. Ancak vergi otoritesi işletmeye vergi uygulayarak işletmenin maliyetlerini artırır ise, birim üretim başına ortalama değişken maliyeti artan işletme artık daha az üretim yapacaktır. Çok yüksek bir vergi işletmenin tüm faaliyetini sona erdirebilecekken, vergiyi ayarlayarak üretim istenilen ölçüde kısılabilecektir. Sonuçta, işletmenin üretiminden toplumun sağladığı yarar ile toplumun katlandığı maliyet eşitlenecektir.

Son dönemlerde, global sermaye akımları hız kazanmış ve dünya döviz piyasasında işlem hacmi çok yüksek boyutlara ulaşmıştır. Döviz işlemleri üzerinden alınacak küçük bir vergi ile bu aşırı işlem miktarını azaltmak mümkün görünmektedir. Böyle bir vergi sermayenin hareketliliğini bir miktar kısitlayacaktır. Sonuçta Tobin Vergisi, kriz yarattığı ölçüde sosyal bir maliyete de yol açmakta olan kısa vadeli sermaye hareketlerinin yatırımcıya maliyetinin artırılması suretiyle aşırı işlem hacmini azaltmak amacını gütmektedir. Önerinin dikkat çeken yanı, oldukça küçük oranlı bir verginin bile kısa vadeli sermaye hareketlerinde maliyeti anlamlı bir biçimde artırırken uzun vadeli yatırımlar ve ticaret amaçlı döviz işlemlerini etkilemeyecek olmasıdır. Döviz işlemleri kontratlarının vade yapısına bakıldığında ağırlıklı olarak vadelerin oldukça kısa olduğu dikkat çekmektedir. Bu durum global sermaye akımlarının da oldukça kısa vadede yön değiştirebildiğinin bir göstergesidir.

Yurtiçi faiz oranlarının $i_{y}$, dünyadaki faiz oranlarının ise $i_{d}$, Tobin Vergisi'nin $t$, yatırımın süresinin de $s$ kadar olduğu varsayımı altında dış alemden yurtiçine yatırım gerçekleştirilmesi için; $\left(1+\mathrm{i}_{y} \times s\right)(1-t)^{2}=\left(1+\mathrm{i}_{d} \times s\right)$ eşitliğinin sağlanması gerekir. (1-t)'nin karesinin alınmasının nedeni yatırımcının $t$ kadar vergiyi hem yurtiçine girişte hem de parasını yurtdışına çıkarırken yapacağı döviz işlemlerinde iki defa ödeyecek olmasıdır. Bu eşitlik kullanılarak yurtiçindeki likit yabancı sermayenin yurtdışına çıkması için gereken faiz oranı seviyesi hesaplanırsa; 
$i_{y}=\left[\left(1+i_{d} \times s\right)-(1-t)^{2}\right] /\left[(1-t)^{2} \times s\right]$ eşitliği bulunacaktır. Bu eşitlik, hem pay hem de paydasında yer alan $s$ ile sadeleştirildiğinde; $i_{y}=\left[i_{d}+(t / s)(2-t)\right] /\left[(1-t)^{2}\right]$ eşitliği elde edilecektir.

Yurtdışında faiz oranlarının \%5, Tobin Vergisinin \%1 olduğu kabul edilirse, 1 yıllık bir yatırım planına sahip yatırımcının (risk primi dahil edilmeksizin) gelişmekte olan bir piyasada faizlerin $\% 7$ olmasını beklemesi gerekecektir. ${ }^{9}$ Oysa yatırım planı üç aylık $(s=1 / 4)$ olan bir yatırımcının dışarıda faiz oranları \%13 olmadan parasını yurtdışına çıkarması kendisi için faiz zararına yol açacaktır. Bir ay için yurtdışına çıkan bir yatırımcı içinse dışarıdaki faizlerin \%29 olması gerekecektir. Açık bir biçimde böyle bir vergi en çok kısa vadeli yatırım kararlarını etkileyecektir.

Eğer eşitliğimizi bu defa optimal vergi oranının bulunması amacıyla çözecek olursak, şu eşitliği elde ederiz: $t^{*}=\left[\left(1+i_{y} \times s\right)^{1 / 2}-\left(1+i_{d} \times s\right)^{1 / 2}\right] /\left(1+i_{y} \times s\right)^{1 / 2}$. Burada $t^{*}$ optimal vergi seviyesini göstermektedir. $\mathrm{Bu}$ eşitlikten yararlanarak yurtiçi faizlerin $\% 20$, yurtdış1 faizlerin $\% 5$ olduğu bir durumda, bir haftaya kadar olan işlemleri azaltmayı hedefleyen bir vergi oranı $\% 0,14$ olacaktır. Bir aya kadar olan işlemleri azaltmayı hedefleyen bir verginin ise \%0,61 olması gerekecektir. Tobin Vergisi global ticaretten kaynaklanan döviz işlemlerini engellemeyecek kadar düşük vergi oranları ile kısa vadeli sermaye hareketlerini sınırlandırabilecektir.

\subsubsection{Tobin Vergisi Üzerine Tartışmalar}

Tobin Vergisi'nin hangi ülkeler tarafından, hangi işlemlere uygulanması gerektiği üzerinde tartışmalar devam etmektedir. Tobin tarafından tüm dünyada eşanlı olarak uygulamaya geçirilmesinin gerektiği ifade edilen verginin, eğer bu sağlanmazsa vergiyi uygulayan ülkelerdeki döviz işlemlerinin hızla vergiyi uygulamayan ülkelere kayması sonucunu doğuracağı ifade edilmektedir. Vergi cennetleri olarak adlandırılabilecek bu tip piyasaların oluşmaması için etkili olabilecek bir öneri, dünyanın önde gelen finans piyasalarında bu ülkelerle yapılacak döviz transferi işlemlerinde en az Tobin Vergisi'nin 2 katı kadar bir işlem vergisinin alınmasıdır. Bu sayede vergiyi uygulamayan ülkelerin herhangi bir maliyet avantajı da kalmayacaktır. Bu önerinin etkili olabilmesi için küresel döviz piyasasının \%76'ünü oluşturan 6 ülkenin katılımı yeterli olacaktır. ${ }^{10}$ Böylelikle küresel döviz piyasasında ağırlığı olan 6 ülkenin benimsemesi halinde Tobin

\footnotetext{
$9 i_{d}=0,05, \quad t=0,01$ ve $s=1$ iken $i_{y}=(0,05+(0,01 / 1) \times(2-0,01)) /(1-0,01)^{2}$ eşitliği çözüldüğünde $i_{y}=0,07$ sonucuna ulaşılmaktadır.

${ }^{10}$ Küresel döviz piyasasının toplam işlem hacmi olarak \%76'sını kontrol eden ilk altı ülke, 2010 itibariyle yıllık küresel işlem hacmi içerisindeki yüzde payları ile şunlardır: \%37 pay ile 1. Birleşik Krallık, $\% 17$ pay ile 2 . ABD, $\% 6$ pay ile 3. Japonya ve herbiri $\% 5$ pay ile $4 ., 5$. ve 6 . İsviçre, Hong Kong ve Singapur. Bkz. Bank for International Settlements (2010), s. 19, tablo B.8.
} 
Vergisi'nin dünya çapında hayata geçirilmesi mümkün olabilecektir. Bu oluşumun dışında yer almak ise ülkeler açısından istenmeyen bir durum haline gelebilecektir.

Tobin Vergisi'nin kapsamı konusunda da çeşitli görüşler ileri sürülmektedir. Verginin, sadece spot piyasa işlemlerini mi kapsayacağ 1 yoksa vadeli işlem piyasalarını da mı kapsaması gerektiği konusunda net bir görüş yoktur. Ancak, günlük işlem hacminin önemli bir kısmının vadeli işlemler biçiminde gerçekleştiği ve vadeli işlem piyasasında yapılan forward işlemlerinin \%46'inin, swap işlemlerinin ise \%74'ünün en fazla bir hafta vadeli olduğu göz önüne alındığında verginin istenen etkiyi yapabilmesi için vadeli işlemleri de kapsayacak biçimde uygulanması gerektiği ortaya çıkmaktadır. Başka bir ifadeyle vergi bütün döviz işlemlerini kapsayacak biçimde konulmalıdır. ${ }^{11}$

Öte yandan, pozisyon kapama işlemleri için bankalararası para piyasasında yapılacak günlük döviz işlemleri gibi döviz piyasasında istikrarsızlık yaratmayacak, ancak vergilendirildiğinde kurumsal işlemcilere oldukça yüksek maliyet getirecek bazı işlemlerin vergiden muaf tutulabileceği ifade edilmektedir. Ayrıca, merkez bankası ve piyasa yapıcı kurumlar gibi döviz piyasasında istikrarın sağlanmasına yönelik işlem yapan kurumların bu tür işlemlerinin de vergiden muaf tutulması gerektiği belirtilmektedir.

Sonuç olarak, Tobin Vergisi her ne kadar piyasa düzenleyici bir vergi olarak düşünülse de her vergi gibi gelir yaratıcı etkisi olacaktır. Global döviz piyasasının günlük hacmi düşünüldüğünde çok küçük oranlı bir verginin bile y1llık bazda çok ciddi miktarda vergi geliri yaratması söz konusudur. Böyle bir vergi henüz uygulanmamış olduğundan döviz işlemleri hacminin elastikiyeti bilinememektedir. Ancak \%0,1 oranında uygulanacak ve halen \$4 trilyonluk günlük işlem hacmi miktarını yarı yarıya azaltacak bir verginin bile 220 iş günü üzerinden hesaplandığında \$440 milyar vergi geliri yaratması söz konusu olacaktır. Yukarıda bahsedildiği gibi çeşitli işlemler vergiden muaf tutulsa ve işlemlerin çok daha fazla bir elastikiyete sahip olduğu düşünülse bile verginin çok önemli bir gelir yaratıcı etkisinin olduğu kabul edilmektedir. Bu geliri hangi kurumun toplayacağ 1 ve ne amaçla harcayacağ 1 tartışılan bir başka konudur. Global bir Tobin Vergisi kuruluşunun kurulup, gelirin global kalkınmaya yönelik projelerin finansmanına harcanması yanında verginin ulusal bazda toplanıp, her ülke tarafindan global kalkınmaya hizmet eden Dünya Bankası ve benzeri örgütlere aktarılması üzerinde durulan önerilerdir. Bir başka görüş ise, verginin ulusal bazda toplanması, ancak gelişmiş ülkeler tarafından toplanan gelirin uluslararası kalkınma örgütlerine aktarılırken, gelişmekte olan ülkelerce yurtiçinde bütçeye vergi geliri olarak

\footnotetext{
${ }^{11}$ Yüzde oranlar BIS verilerinden hesaplanmıştır. Bkz. Bank for International Settlements, a.g.e. sf. 7, tablo B.1.
} 
kaydedilmesi ve kamu hizmetlerinin finansmanında kullanılması yönündedir (Karataş ve Söylemez, 2005: 18).

\subsubsection{Eichengreen ve Wyplosz Vergisi}

Barry Eichengreen ve Charles Wyplosz, sermaye çıkışları üzerinden alınacak bir vergi ile sermayenin yurtdışına ani çıkışlarından kaynaklanan ödemeler dengesi sorunlarının hafifletilebileceğini ve bu sayede uluslararası finansal dalgalanmaların büyük oranda azaltılabileceğini ileri sürmüşlerdir. ${ }^{12}$ Tobin Vergisi tüm dünyada uygulanması önerilen bir çözüm aracıyken Eichengreen ve Wyplosz'un önerisi ülkeler tarafindan tek başlarına da uygulanabilecektir. Uluslararası sermayenin ülkeye girdiği tarihten çıkışına kadar geçen süre boyunca vergi oranının kademeli olarak düşürülmesi önerilmekte, böylece ülkeye kısa vadeli spekülatif amaçlarla giren yatırımcıların getirileri ciddi oranda azaltılırken, daha uzun vadeli yatırımların fazla bir vergi yüküyle karşılaşmaması mümkün olabilecektir. Ayrıca, verginin yurtiçi faiz oranlarına paralel biçimde artırılıp azaltılması da gerekmektedir. Aksi takdirde yurtiçi faiz oranlarının yükseldiği zamanlarda verginin etkinliği de azalacaktır (Karataş ve Söylemez, 2005: 19).

\subsection{3 Şili’nin Kontrol Uygulamaları}

Şili liberalleşme politikalarını diğer Latin Amerika ülkelerinden daha hızlı ve kapsamlı bir biçimde 1980'li yılların ilk yarısında tamamlamıştır. 1978-1982 yılları arasında uygulanan program, finansal liberalizasyon sürecini hızlandırmıştır. 1974 yılında bankaların özelleştirilmesi, faiz oranlarının serbest bırakılması ile başlayan liberalleşme politikaları, 1979 yılında sermaye hareketlerinin liberalleştirilmesi ile devam etmiştir. Orta ve uzun vadeli sermaye hareketlerinden sonra 1982 yılında kısa vadeli sermaye girişleri üzerindeki sınırlamalar da kaldırılmıştır. 1977 yılında $\$ 677$ milyon olan sermaye girişi, 1981 yılında $\$ 4,8$ milyara yükselmiştir. Şili’nin övgü toplayan bir serbest piyasa ekonomisi olmasına rağmen, ülke 1991 yılında kısa vadeli sermaye girişleri üzerine sınırlamalar getirmiştir. Şili sermaye hareketlerini üç farklı yöntemle kontrol etmektedir. İlk kontrol yöntemi, ülkeye hisse alımı dışında bir yoldan giren sermayenin \%30'luk kısmının merkez bankasında faizsiz bir hesapta en az bir yıl tutulmasıdır. Bu uygulama, vergi benzeri bir etkide bulunarak ülkeye giren sermaye için giriş maliyetini artırmaktadır.

İkinci kontrol yöntemi ise, Şili banka ve şirketlerinin uluslararası borçlanma yapabilmeleri için en az iki rating kuruluşu tarafindan Şili devlet tahvilleri ile aynı veya daha iyi bir rating ile değerlendirilmiş olmalarının zorunlu tutulmasıdır. Üçüncü kontrol yöntemi ise Şili'ye giren her yabancı sermaye yatırımının ülkede en az bir yıl kalmasının zorunlu olmasıdır. Bu uygulama özellikle kısa vadeli hareket

\footnotetext{
${ }^{12}$ Frankel (1996, s.27) ve Frankel (1999).
} 
eden hedge fonlarının Şili'ye girişlerini engellemektedir. Sermaye hareketleri girişlerine getirilen sınırlamaların etkisiyle Şili'ye giriş yapan sermayenin hem kompozisyonu hem de hacmi değişmiştir. Uzun vadeli sermaye hareketlerinde artış görülmüştür. ${ }^{13}$

$\mathrm{Bu}$ üç uygulama arasında en dikkat çekeni, hisse yatırımı dişında bir amaçla yurda giren sermayenin belirli bir oranının merkez bankasında faizsiz biçimde bloke edilmesidir. Nitekim, diğer iki uygulama direkt kontroller kapsamında değerlendirilebilecek uygulamalarken, merkez bankası blokaj1 vergi benzeri bir etkide bulunarak ve sermaye hareketlerinin vade yapısına bağlı olarak maliyetini artıran modern bir uygulamadır. Sözkonusu uygulamadan dolayı yurda giren paranın belirli bir yüzdesi belirli bir dönem için piyasadaki getiri imkânlarından faydalanamamakta, böylece bir firsat maliyetine katlanmaktadır. Sermayenin bloke edilmemiş kısmının kısa vadede yüksek getiri sağlama amacıyla ülkeden çıkması ise bloke edilen tutar nedeniyle anlamlı olmamaktadır.

\subsubsection{Spahn Vergisi}

Spahn vergisi 1995 yılında Goethe Üniversitesi’nden Paul Bernd Spahn tarafindan önerilmiş olan ve döviz kurlarındaki aşırı oynaklığı hedefleyen bir vergidir. Spahn vergisinin dayandığı temel fikir normal zamanlarda likidite işlemleri ile spekülatif alım-satım işlemlerini ayırd etmenin imkansız olduğudur. $\mathrm{Bu}$ nedenle Spahn vergisi iki katmanlı olarak tasarlanmıştır. Öncelikle oldukça küçük oranda bir finansal işlemler vergisinin daima alınması öngörülmektedir. Öte taraftan ise döviz alım satım işlemlerinde sadece döviz piyasasında aşırı oynaklığın ortaya çıktığı durumlarda alınacak ve can yakıcı oranda olacak bir vergi söz konusudur. Böylelikle Spahn vergisi normal zamanlarda likidite durumuna bağlı olarak ortaya çıan ve piyasa bozucu olmayan alım-satım işlemlerinin vergi ile cezalandırılmamasını, ancak döviz kurlarında aşırı oynaklık oluştuğunda devreye otomatik olarak girecek bir vergi oranı artışı ile spekülatif işlemlerin caydırılmasını ve hemen oynaklığın düşürülmesini öngörmektedir.

\subsubsection{Finansal İstikrarı Hedefleyen Yeni Dönem Merkez Bankacılığı Uygulamaları}

2008 y1lında patlak veren küresel finansal sorunlar neticesinde yeni bir merkez bankacılığı anlayışı şekillenmeye başlamıştır. 2008 sonrası bu yeni dönemde merkez bankaları finansal istikrarı sağlamayı bir hedef olarak geleneksel fiyat istikrarı hedefinin yanına eklemişlerdir. Finansal istikrar kavramının bu kadar öne çıkmış olmasının nedeni 2008 yılında yaşanan sorunların Amerika ve Avrupa ekonomileri gibi gelişmiş ekonomilerde ortaya çıkmış olmasıdır. Bu sayede,

\footnotetext{
${ }^{13}$ Ancak Şili uygulamalarının başarısını sorgulayan ve hatta Şili örneğini tamamen başarısız ilan eden çalışmalar da mevcuttur. Örneğin bkz. Edwards \& Rigobon (2009) ve Forbes (2005).
} 
finansal sistemin gelişmiş ekonomileri bile tehdit edebilecek iç istikrarsızlıklara sahip olduğu fark edilmiştir.

Aslında finansal sistemin iç istikrarsızlıklarının olduğu hususunda fikirler 2008 yılından önce de ortaya çıkmış ve hatta hep var olagelmiştir. Örneğin makalenin yukarıdaki kısımlarında bahsi geçen tarihi kanıtlara dayanarak sermaye kontrolünü savunan fikirlerin ortaya çıkışında etkili rol oynayan kitabını Charles Kindleberger ilk olarak 1978 yılında yayınlamıştır. Ancak ne kadar taraftar toplasa da uluslararası sermayenin kontrole ihtiyacı olduğu hususundaki fikirler 2008 yılına kadar en azından uluslararası iktisadi düzeni belirleyen IMF, Dünya Bankası, ABD Hazinesi, birçok gelişmiş ülke merkez bankası gibi kurumlarca genel kabul görmemiştir. 2008 yılından önce bir grup iktisatçı finansal istikrarsızlıkların ortaya çıkmadan engellenmesi gerektiği hakkında fikir bildirmeye başlamış ve bu sayede 'lean against the wind' olarak bilinen bir literatür oluşmuştur. ${ }^{14}$ Söz konusu literatüre göre merkez bankaları varlık fiyatlarında artışlar oluşmadan önce faizleri artırmak suretiyle balon oluşumunu engellemeli ve bu yolla finansal istikrarı korumalıdır. Ancak 2008 öncesinde bu görüşün karşısında, başını eski ABD merkez bankaları sistemi (Federal Reserve sistemi) başkanı Alan Greenspan'in çektiği bir başka görüş oluşmuştur. $\mathrm{Bu}$ ikinci görüşün taraftarlarına göre merkez bankaları kesinlikle varlık fiyatlarındaki şişinmelere tepki vermemeli, ancak eğer bu yolla bir finansal kriz patlak verirse, ortaya çıkan sorunları temizlemelidirler. Bu ikinci görüş taraftarlarına işte bu nedenle 'clean' (yani 'temiz') görüşü taraftarları, ve iki görüş arasındaki tartışmaya da 'lean - clean' tartışması denilmiştir. 2008'de yaşananlardan sonra merkez bankalarının finansal istikrarsızlıkları ortaya çıkmadan hedef alması gerektiği (lean against the wind) yaklaşımı ağırlık kazanmıştır. ${ }^{15}$

Lean - clean tartışmasının odak noktasını, para politikasının varlık fiyatları balonlarına tepki verip vermemesi gerektiği üzerine yapılan tartışmalar oluşturmuştur. Ancak 2008 yılındaki çöküşle beraber emlak piyasasındaki fiyat balonlarının, kredi piyasası ile etkileşimi oldukça net biçimde ortaya çıkmıştır. Bu sayede de şu gerçek fark edilmiştir: eğer bir balon oluşmaya başlamışsa, finansal istikrarsılılı için asıl dikkat edilmesi gereken nokta, bu balonun temelinde aşırı kredi artışları mı yoksa piyasa ajanlarının akılsız coşkusu mu olduğudur. Mishkin'e göre asıl yıkıcı etkiler, kredi artışları neticesinde oluşan varlık fiyatları balonları nedeniyle ortaya çıkmaktadır. Bunun sebebi ise kredi artışlarının sebep olduğu varlık balonlarının banka bilançolarını da bozmasıdır. İşte bu nedenle, balon patladığında sorunlar tüm ekonomiye bankacılık sistemi yoluyla yayılmaktadır.

\footnotetext{
${ }^{14}$ Lean against the wind taraftarı olan yazılar için bkz. Cecchetti ve diğerleri (2000), Borio ve Lowe (2002), Borio, English \& Filardo (2003) ve White (2004).

${ }^{15}$ Bkz. Mishkin (2011, s.60).
} 
Ancak piyasa ajanlarının akılsız coşkusu sebebiyle ortaya çıkan balonlar patladığında yatırımcılar bütün zararı üstlenmektedir. ${ }^{16}$

$\mathrm{Bu}$ yeni dönemde Türkiye Cumhuriyet Merkez Bankası (TCMB) da finansal istikrarı açıkça hedeflemeye başlamıştır. TCMB, düşük faiz ortamı yaratarak yurtdışından Türkiye'ye yönelen portföy yatırımlarını azaltmaya çalışmaktadır. Bu sayede bir risk unsuru olan cari açığın kontrol altına alınması hedeflenmektedir. Ancak düşük faiz ortamında yurtiçi krediler artabilecektir. İşte bu nedenle de TCMB mevduat munzam karşılıklarını artırmak gibi yurtiçi kredi oluşumunu azaltacak politikalar uygulamaya koymaktadır. Kredi artışlarındaki yüksek hızın düşürülmesinin hedeflenmesi az önce bahsedilen aşırı kredi ile beslenen balonların tehlikeleri nedeniyle olumludur. Nitekim kredi artışları, yıkıcı etkilere sahip olabilecek varlık balonlarını tetikleyebilmektedir. Ancak, TCMB'nin politikası bu haliyle bankaların bilanço yapılarında değişiklik yapmalarına ve yurtdışından kaynak toplamaya yönelmelerine neden olabilmektedir.

Aslına bakılırsa, yüksek miktarda ve oynaklıkta gerçekleşen sermaye akımlarının da, bu akımlar sayesinde ortaya çıkan kredi arzı genişlemesi ve daralması hallerinin de altında düzeltilmeyi bekleyen piyasa yanlışları var olabilir. Örneğin tipik bir kredi arzı olayını ele alırsak, arz edilen kredinin negatif dışsallıkla arz edildiğini rahatlıkla iddia edebiliriz. Zira finansal aracı kurumların verdiği krediler eğer geri ödenirse finansal aracıya kâr sağlamakta ancak temerrüte düşerse tüm topluma maliyet yükleyebilmektedir. Çünkü krediler topluca temerrüde düşmeye başlarsa bu durum finansal sistemin sağlığının sorgulanmasına yol açabilir ve böyle bir sorgulama durumu ise faizlerin artmasına ve hatta bir kriz çıkmasına neden olabilir. Şu halde kredi verirken, finansal aracı kurumlar bu tür sosyal maliyetleri ödemiyorlarsa, krediler olması gerekenden daha az maliyetle verilebilecek ve bu yanlış fiyat sinyali nedeniyle de olması gerekenden daha çok miktarda kredi verilebilecektir. Burada anlatılan tipik bir negatif dışsallık örneğidir ve düzeltilmesi için Pigou tarzı bir düzeltici verginin kullanılabileceği iktisat teorisi tarafindan ortaya konulmuştur. Zaten Tobin vergisi de aşırı miktarda gerçekleşen uluslararası finansal işlemlerin miktarının azaltılmasına yönelik bir tür Pigou vergisi olarak ele alınabilir.

Şu halde, uluslararası sermayenin kontrol altına alınabilmesi için uluslararası sermayenin aşırılıklarının (miktar ve oynaklık) neden kaynaklandığının ve hangi tür piyasa yanlışlarına bağlı olduğunun anlaşılması ve ona göre çözüm üretilmesi daha uygun olabilir. Başkaca bir deyişle, belki sade bir vergi düzenlemesiyle düzeltilebilecek bir durum için merkez bankalarının para politikası araçlarını kullanmalarının bir gereği olmayabilir. Bu durumda 2008 sonrası dönemde finansal istikrarı da bir hedef haline getirmiş bulunan ve artık çoklu hedeflemeye yönelmiş

${ }^{16}$ Mishkin, a.g.e., s.62. 
olan, bunun neticesinde de çoklu araç kullanmak zorunda kalan merkez bankaları tekrar sadece fiyat istikrarı hedefine odaklanabilecek ve finansal istikrarın sağlanması hedefini vergiden sorumlu otoriteye (maliye bakanlığı) tevdi edebileceklerdir. Ancak şunun not edilmesi gerekir ki bu satırlar bir çözüm önerisi olması iddiasıyla değil, önemli bir araştırma konusuna dikkat çekmek amaciyla yazılmıştır. Gelecekte, uluslararası sermayenin muzdarip olduğu piyasa yanlışlarını ve bu yanlışların olası çözümlerini ortaya koyacak çalışmalar iktisat literatürüne büyük katkı sağlayacaktır.

\section{AB'de Sermaye Kontrolü Hakkındaki Tartışmalar ve Çeşitli Ülke Uygulamaları}

AB üyesi ülkelerden İsveç 1983 yılında sermaye kontrolüne yarayacak türden bir finansal işlemler vergisini kullanmaya başlamış, söz konusu vergi 1991 yılına kadar yürürlükte kalmış ancak arada geçen sekiz yılda vergiden istenilen yararlar elde edilememiştir. İsveç'in uyguladığı vergi sadece döviz alım-satımı üzerine salınmamış, çok daha geniş bir finansal işlemler vergisi olarak tasarlanmıştır. Değişen vergi oranları hisse senedi piyasasındaki basit alım-satım işlemlerinden, bono ve tahvil piyasası işlemlerine ve oradan da türev araç piyasalarına kadar uygulanmıştır. İsveç uygulaması bir finansal işlem vergisi olmasından ötürü genellikle Tobin vergisi olarak anılsa bile, yukarıda Tobin vergisinin teorik temellerini açıkladığımız bölümde bahsedilen tam (saf) bir Tobin vergisinin özelliklerini taşımamaktadır. Öncelikle James Tobin tarafından önerilen vergi tüm dünyada eş anlı uygulanması önerilen bir vergi iken İsveç'in bahsi geçen finansal işlem vergisi sadece İsveç'in kendi özel uygulaması olmuştur. Sonuçta söz konusu vergi İsveç’ten sermaye kaçısına neden olmuş, İsveç finans piyasalarında işlem yapan bazı yatırımcılar vergiden kaçabilmek için Oslo ya da Londra'ya yönelmiştir. ${ }^{17}$ Ayrıca vergiyi salan Sosyal Demokrat hükümet, vergiden gelir elde etmeyi de ummuştur. Tobin vergisi de diğer vergiler gibi gelir yaratma kabiliyeti haiz ancak gelir artırıcı özelliğinden ziyade piyasa yanlışlarını düzeltici yanıyla önem arz eden bir vergidir. Başkaca bir ifadeyle, örneğin negatif ekonomik dışsallıklar nedeniyle yurtdışından ülkeye fazlaca kısa vadeli portföy yatırımı aktığını ve bu gelen paranın kredi arzında bir şişinmeye neden olduğunu düşünüyorsanız, dışsallıklardan kaynaklanan sosyal maliyetin ödenmeme durumunu Tobin vergisi gibi bir vergi ile portföy yatırımcılarına ödetir ve toplam portföy yatırımı miktarına bu yolla toplumsal optimuma çekersiniz. Ancak bu tür bir vergiyi öncelikle gelir yaratmak için düşünmezsiniz. İşte bu noktada İsveç uygulaması hatalıdır. Zaten hükümetin öngördüğü ve sadece sabit getirili yatırım araçlarından sağlanması umulan yıllık ortalama 1.5 milyar İsveç Kronu tutarındaki vergi gelirine karşılık 1983-1991 dönemindeki y1llık ortalama gelir 50 milyon İsveç Kronu

${ }^{17}$ Aslund (2011). 
olmuştur. Bu durumun da sebebi ya az once belirttiğimiz gibi finans yatırımcısının başka merkezlere kayması ya da İsveç içerisinde yatırımların vergilendirilmemiş ürünlerde yoğunlaşmasıdır (örneğin forward işlemler ve takaslar). ${ }^{18}$

Bugün Euro Alanı'ndaki borç problemleri neticesinde, İsveç'in 1980'ler boyunca tecrübe ettiğine benzer bir finansal işlem vergisinin $A B$ alanında uygulanması tartışmaları yaşanmaktadır. Bu vergiden amaç borç batağına saplanmış Euro Alanı ülkelerine ve zor durumdaki bankacılık sistemine parasal destek sağlayacak gelirin elde edilmesi yanında, riskli finansal işlemlerin maliyetini artırmak suretiyle miktarını azaltmak ve finansal krizin yıkıcılığını artıran türev ürünlerin kullanımını kontrol etmektir. ${ }^{19}$ En son 22 Ocak 2013 tarihinde aralarında Almanya ve Fransa'nın da bulunduğu 11 ülke ileriki bir tarihte ortak bir finansal işlem vergisi uygulama hususunda görüş birliğine vardıklarını ilan etmiştir. ${ }^{20}$ Ancak 15 diğer ülke halen ikna edilebilmiş değildir. Bunlardan İngiltere ve İsveç'in tüm AB'de hayata geçirilecek bir finansal işlem vergisine şiddetle karşı oldukları bilinmektedir. İsveç yukarıda belirtildiği üzere kötü tecrübeye sahiptir. İngiltere ise dünyanın en büyük finansal merkezlerinden birisidir, hatta döviz işlemleri piyasası olarak dünyanın en büyüğüdür. İngiliz yetkililer bir finansal işlemler vergisinin yatırımcıları dünyanın diğer uçlarındaki finansal merkezlere kaydırabileceğinden endişe etmektedir.

AB'nin tartıştığı haliyle konulması planlanan vergi ile tüm hisse yatırımları ve sabit getirili yatırımlar üzerinden yatırımın $\% 0.1$, tüm türev işlemlerden ise kontrat bedelinin \%0.01'i kadar bir vergi alınması öngörülmektedir. Vergi halka arz ve banka kredilerini kapsamayacaktır. Böyle bir verginin, sadece konuya 1lımlı bakan 11 ülkede uygulansa bile, yıllık $€ 35$ milyar gelir getirebileceği ifade edilmektedir. Ancak bu haliyle düşünüldüğünde $\mathrm{AB}$ alanında tartışmaya konu olan verginin de Tobin vergisi olmakla uzaktan yakından alakası olmadığı görülebilmektedir. Nitekim, vergi yine gelir artırma amaçlı olarak düşünülmekte ama piyasa yanlışlarını düzeltici etkisi ile değerlendirilmemektedir. Dahası eğer piyasa yanlışları hedeflense kesinlikle vergi ile düzenlemeye tabi olacak, likidite bolluğu durumunda aşırı kredi dağıtılması sorunu göz ardı edilmekte ve banka kredilerine ilişkin bir vergi düzenlemesi planlanmamaktadır. Oysa yukarıda Frederick Mishkin'in fikirlerini alıntılarken de belirttiğimiz üzere aşırı kredi verilmesi durumunda ortaya çıkabilen fiyat balonları finansal sistem üzerindeki en etkili

\footnotetext{
${ }^{18}$ Information Daily Focus Report.

${ }^{19}$ Griffith (2013).

${ }^{20}$ Verginin hayata geçirilebileceği tarih olarak Avrupa Komisyonu bir öneri olması amacıyla 2014 yılını belirlemiştir. Komisyona göre Avrupa Merkez Bankası, Avrupa İstikrar Mekanizması ve Avrupa Finansal İstikrar Fonu işlemlerinin vergiden muaf olacaktır. Genel bir finansal işlemler vergisi koyulması üzerinde mutabık kalmış 11 ülke şunlardır: Fransa, Almanya, Belçika, Estonya, Yunanistan, İspanya, İtalya, Avusturya, Portekiz, Slovenya ve Slovakya'dır. Detaylı bilgi için bkz. Tax the World: EU's Controversial Tobin Tax Might Take Effect in 2014.
} 
tehditler arasındadır. $\mathrm{Bu}$ temel hatanın yanında başka eleştiri noktaları da mevcuttur. Öncelikle finansal ürünler üzerine vergi konulması, AB gibi finansal sistemin çok gelişkin olduğu ve bu nedenle kolayca vergi dışında kalabilecek ürünleri geliştirebilecek bir yerde uygulamak kolay olmayacaktır. Ikinci olarak spekülasyonun azalması sağlansa bile iktisat literatürüne göre spekülasyonun likidite artırıcı yararları mecvuttur ve özellikle Euro Alanı'nda ihtiyaç duyulan likidite azalabilecektir. Ayrıca Avrupa bankacılık sisteminin kar marjları daralmış durumdadır. Böyle bir ek vergi maliyetiyle birlikte bazı bankaların ayakta kalabilmek için birleşme yoluna girebileceği ve bunun bankacılık alanında bir konsolidasyon yaratabileceği ifade edilmektedir. AB alanındaki özel emeklilik fonlarının getirileri de düşecek ve bu durum Avrupa'nın yaşlı emekli nüfusunun refajını olumsuz etkileyecektir. Avrupa'dan başka merkezlere yatırımcı kaçısı olabilecek ve ülkelerin milli gelirlerinde potansiyel bir azalma ortaya çıkacaktır. ${ }^{21}$

$\mathrm{AB}$ alanının tümünde geçerli olması fikriye ortaya atılan söz konusu vergiye İsveç ve İngiltere'den başka Güney Kıbrıs ve Lüksemburg'un da kıyı bankacılığı merkezleriyle finansal rekabet içerisinde kalabilmek için öteden beri karşı oldukları bilinmektedir. Ancak Güney Kıbrıs, yaşanan son gelişmelerden sonra artık kendisi en direkt haliyle sermaye kontrolü uygular hale gelmiştir. Güney Kıbrıs'ın 2013 yılı Mart ayı sonunda AB otoriteleri ve IMF ile birlikle kararlaştırdığı, Güney Kıbrıs’ta mevduat sahiplerinin paralarını bankacılık sisteminden acilen talep etmelerinin önüne geçebilmek ve buy olla ortaya çıkacak bir likidite krizini önlemek amacıyla kısa süreli olarak düşünülmüş bulunan sermaye kontrolü uygulamalarına göre bankalardan çekilebilecek mevduat tutarı sınırlandırılmış, çek ödemeleri durdurulmuş ve Güney Kıbrıs menşeili kredi kartlarının yurtdışında kullanılmasına kısıtlar getirilmiştir. Bu tür direkt kısıtlamalar yakın zamanda AB'de sadece Güney Kıbrıs'ta değil, 2011'de İzlanda'da da uygulanmıştır. ${ }^{22}$ Güney Kıbrıs ve İzlanda haricinde sermaye kontrolüne yönelmiş bir başka $\mathrm{AB}$ üyesi ise İtalya'dır. İtalya 2013 y1lı başlarında alınan bir kararla 1 Mart 2013 ile 1 Haziran 2013 tarihleri arasında çeşitli finansal işlemleri kapsayacak biçimde kademe kademe yürürlüğe girecek bir finansal işlemler vergisini yasalaştırmışıır. ${ }^{23}$

Son olarak, henüz 2008 krizi yaşanmadan önce, 1 Temmuz 2004 yılında Belçika Parlementosu Belçika topraklarında gerçekleştirilen finansal işlemlerden Spahn vergisi alınması hakkında yasa çıkartmıştır. Söz konusu yasaya göre $€ 10.000$ tutarındaki her işlemden $€ 2$ tutarında vergi alınması ve toplanan vergi gelirinin üçüncü dünya ülkelerinde kalkınma projelerine harcanması kararlaştırılmıştır. €2 tutarındaki vergi finansal kriz dönemlerinde aşırı devalüasyon tehdidini ortadan kaldırmak amacıyla artırılacaktır. Vergi yasası yürürlüğe Euro Alanı'ndaki her ülke

\footnotetext{
${ }^{21}$ Griffith, Saul, a.g.e.

${ }^{22}$ South China Morning Post, 28 Mart 2013.

${ }^{23}$ Norton Rose Report, Şubat 2013.
} 
benzer bir vergi yasası çıkarttıktan sonra girecektir. Başka bir ifadeyle AB alanında birçok ülkede çeşitli vergilerle finansal işlemlerin miktarının azaltılması hem tartışılmaktadır, hem de bu konuda çeşitli ülkelerde uygulamalar görülmeye, mevzuat oluşmaya başlamıştır.

Bütün bu vergi temelli ya da direkt yollardan sermaye kontrolü tartışmalarının yanında Avrupa Merkez Bankası'nın (AMB) durumuna da göz atacak olursak, AMB'nın finansal istikrarı 2008'den sonra daha çok gözettiği ama finansal istikrarı sağlamak için bundan böyle uyguayacağı aktif politikalar oluşturmak yerine hali hazırda krizin yarattığı durumu temizlemeye çabaladığı yani yukarıda bahsettiğimiz 'lean vs clean' tartışması uyarınca cleaning (temizleme) görevini ifa ettiği, ama bundan böyle finansal istikrarsızlıkların oluşmaması için politikalar dizayn edip etmeyeceğinin belli olmadığı görülmektedir. AMB halen fiyat istikrarını kuvvetli bir biçimde vurgulayarak öncül hedefi olarak ifade etmektedir. Finansal sisteme yardım ve istikrarı muhafaza etmek amacıyla AMB'nin şu ana uyguladığ politikalar kabaca şunlardır. AMB sabit oranda faizle piyasaya ihtiyaç oldukça likidite sağlamış, merkez bankası kredilerinin vadesini uzatmış, merkez bankası kredileri için ipotek olarak kabul edilen ürünlerin tanımını genişletmiş, hükümet tahvil ve bonolarını alarak bankacılık sistemine ve piyasalara likidite sağlamış ve munzam karşılık oranlarını düşürmüştür. Görüldüğü gibi bu politikalar istikrar sağlama hedefine yönelik olan ve sermaye kontrolüne yönelik olmayan politikalardır. Şu halde, AB'de sermaye kontrolleri birçok ülkede ya tartışılmakta ya da çeşitli yöntemlerle (vergi ya da direkt yöntemler) bilfiil uygulanmakta olan bir konudur. Ancak AMB, sermaye kontrollerine yönelik olarak aktif politikalar geliştirmemiştir.

\section{Sonuçlar}

Son kırk yılda birçok ülke ödemeler dengesinin bir alt hesabı olan sermaye hesapları üzerindeki kontrolleri kaldırarak ülkelerine uluslararası sermaye giriş ve çıkışlarının önünü açmıştır. Bu serbesleştirme hareketinin teorik temelinde serbest bırakılmış sermayenin tüm dünyada büyümeye, kaynak tahsisine olumlu etkisinin olacağı ve diğer mikro ve makro düzeyde ek yararlar da sağlayacağı düşüncesi yer almıştır. IMF ve Dünya Bankası gibi kuruluşlar da uluslararası sermayeye tam hareket serbestisi tanınması gerektiği düşüncesini benzer gerekçelerle benimsemiştir. Ayrıca eskiden ağırlıklı olarak kamu kurumları ve/veya Dünya Bankası, bölgesel kalkınma bankaları gibi resmi kanallar üzerinden gerçekleşen sınırötesi sermaye işlemleri günümüzde ağırlıklı olarak serbest piyasa temelinde işlem yapan uluslararası özel bankalar ve diğer finansal aracılar üzerinden gerçekleştirilmeye başlamıştır. $\mathrm{Bu}$ değişimlerin sonucunda ise uluslar arasında hareket eden finansal sermayenin mikatarı ve oynaklı̆̆ $\breve{1}_{1}$ artmıştır. Özellikle 1990'lardan itibaren dünyanın çeşitli yerlerinde uluslararası sermayenin hızlı giriş ve çıkışları neticesinde ulusal ya da bölgesel düzeyde finansal krizler yaşanmıştır. 
2008 yılında tüm dünyayı etkileyen ve gelişmiş ekonomilerde baş gösteren finansal çöküşten sonra bazı hallerde uluslararası sermayenin kontrol edilmesinin finansal istikrar açısından yararlı olabileceği fikri artık IMF, Dünya Bankası gibi kuruluşlarda da hakim fikir haline gelmeye başlamıştır. Bu görüş değişimine paralel olarak da sermaye kontrollerinin yöntemleri, merkez bankalarının finansal istikrar hedefi doğrultusunda kısa dönemli portföy yatırımları tarzında gerçekleşen uluslararası sermaye girişlerini azaltacak para politikası uygulayıp uygulamaması gerektiği vb. tartışmalar yoğunlaşmıştır.

2008 yılından sonra AB ekonomisi de Euro Alanı'nda birçok ülkede ortaya çıkan borç krizlerinden olumsuz etkilenmiştir. Bir daha borç krizine düşmek istemeyen ve finansal sistemine istikrar kazandırmayı hedefleyen AB'nde sermaye kontrolleri bu nedenle, üzerinde oldukça tartışılan bir konu haline gelmiştir. Ayrıca bu süreçte borç krizi yaşayan bazı ülkelerin direkt ya da vergi yoluyla bilfiil sermaye kontrolü uygulamaları da olmuştur. Ancak AMB'nın özellikle sermaye akımlarını kontrole yönelik politikalar oluşturmadığı, Avrupa'da sermaye kontrolü kavramının daha ziyade ya vergi yoluyla kontrol ya da direkt kontrol olarak ele alındığı görülmüştür. Son olarak ise tüm $\mathrm{AB}$ alanında geçerli olması istenen ve bu nedenle tartışmalara konu olan bir finansal işlemler vergisi son olarak bir kısım üyenin kararıyla gelecekte 11 Avrupa ülkesinde yürürlüğe girebilecektir. Birçok yazıda Avrupa'nın Tobin vergisi olarak anılan bu vergi ise piyasa yanlışlarını hedef almaması, ancak gelir getirici bir vergi olarak düşünülmüş olması nedeniyle kuruluşunda hatalı bir düzenleme olacaktır.

İşte böyle bir dönemde bu çalışma; sermaye hareketlerinin serbest mi yoksa kontrollü mü olması gerektiği tartışmasını temel alan teorik yaklaşımlar ve sermayenin kontrolü üzerine çeşitli yöntemler üzerine kapsamlı bir inceleme olması amacıyla hazırlanmış ve AB'deki son dönem tartışmalarına bu açılardan bakmıştır. 


\section{References:}

Aslund, Anders (2011), “Sweden's Experience with the Tobin Tax”, Real Time Economic Issues Watch, Peterson Institute for International Economics, www.piie.com/blogs/realtime/? p=2433 Erişim: 29 Mart 2013.

Bank for International Settlements (2010), "Report on Global Foreign Exchange Market Activity”. http://www.bis.org/publ/rpfxf10t.pdf. Erişim: 21 Mart 2013.

Bloomberg, "World Bank Says Asia May Need Capital Controls to Curb Asset Bubbles", 9 Kasim 2010. http://www.bloomberg.com/news/2010-11-08/world-bank-says-asia-mayneed-capital-controls-to-curb-fed-created-bubbles.html, Erişim: 10 Mart 2013.

Borio, Claudio \& Phillip Lowe, (2002), “Asset Prices, Financial and Monetary Stability: Exploring the Nexus”, BIS Working Papers No:114.

Borio, Claudio, William English \& Andrew Filardo, (2003), “A Tale of Two Perspectives: Old or New Challenges for Monetary Policy?", BIS Working Papers No:127.

Cecchetti, Stephen G., Hans Genberg, John Lipsky, \& Sushil Wadhwani, (2000), “Asset Prices and Central Bank Policy", Geneva Reports on the World Economy No.2, International Center for Monetary and Banking Studies and Centre for Economic Policy Research, Geneva.

Edwards, Sebastian \& Roberto Rigobon, (2009), "Capital Controls on Inflows, Exchange Rate Volatility and External Vulnerability”, http://web.mit.edu/rigobon/www/ Robertos_Web_Page/int_-_capcontrols_files/ccev.pdf, Erişim: 15 Mart 2013.

Frankel, Jeffrey, (1996), "How Well Do Foreign Exchange Markets Fuction: Might A Tobin Tax Help?”, NBER Working Paper W5422.

Frankel, Jeffrey, (1999), "Proposals Regarding Restrictions On Capital Flows", The African Finance Journal, 1(1), ss.92-104.

Forbes, Kristin J., (2005), "Capital Controls: Mud in the Wheels of Market Efficiency”, Cato Journal, 25(1), ss.153-166.

G-20, "Coherent Conclusions for the Management of Capital Flows", 15 Ekim 2011. http://www.mofa.go.jp/policy/economy/g20_summit/2011/pdfs/annex05.pdf, Erişim: 10 Mart 2013.

Ghosh, Arish R., Jun Kim, mahvash Saeed Qureshi, Juan Zalduendo, (2012), “Surges”, IMF Working Paper, WP/12/22.

Griffith, Saul, "11 EU Countries Embrace the Tobin Tax", http://www.forexabode.com /forexblog/economy/euro-zone/2013/01/23/11-eu-countries-embrace-the-tobin-tax/ Erişim: 29 Mart 2013.

Information Daily Focus Report, "Tobin Tax: the Swedish Experience", www.tobintax. theinformation daily.com/ archive/id/15. Erişim: 29 Mart 2013. 
International Monetary Fund, "The Liberalization and Management of Capital Flows: An Institutional View", 14 Kasim 2012. http://www.imf.org/external/np/pp/eng/2012/ 111412.pdf, Erişism: 10 Mart 2013.

Karataş, Hatice \& Arif Orçun Söylemez (2005), "Kısa Vadeli Sermaye Hareketleri”, Türkiye Işs Bankası Raporu Eylül 2005, Türkiye İş Bankası İktisadi Araştırmalar Müdürlüğü.

McKinnon, Ronald I., (1973), Money and Capital In Economic Development, Washington D.C., The Brooking Institution.

Mishkin, Frederic S., (2010). "Monetary Policy Flexibility, Risk Management, and Financial Disruptions", Journal of Asian Economics, 23, ss. 242-246.

Mishkin, Frederick S., (2011), "How Should Central Banks Respond to Asset-Price Bubbles? The 'Lean' versus 'Clean' Debate After the GFC", Reserve Bank of Australia Bulletin, http://www.rba.gov.au/publications/bulletin/2011/jun/pdf/bu-0611-8.pdf, Erişim: 14 Mart 2013.

Norton Rose Report, "Italian Financial Transactions Tax - Italy Imposes Tobin Tax on Financial Transactions", Şubat 2013, www.nortonrose.com/knowledge/publications/74950/italian-financial-transactionstax-italy-imposes-tobin-tax-on-financial-transactions. Erişim: 29 Mart 2013.

Quaghebeur, Marc, (2004), "Belgium Supports Tobin Tax", News and Country Digest Nov.29,2004, ss.727-729.

Shaw, Edward, (1973), Financial Deepening In Economic Development, Oxford University Press, New York.

South China Morning Post, "Cyprus to Reopen Banks, Impose Capital Controls”, 28 Mart 2013, http:/www.scmp .com/business/economy/article/1201456/cyprus-reopen-banksimpose-capital-controls. Erişim: 29 Mart 2013.

Söylemez, Arif Orçun, (2004), “Uluslararası Finans Üzerine Tartışmalar ve Türkiye'nin Finansal Serbestleştirme Deneyimi”, Stratejik Öngörü, 1(1), ss.24-33.

Söylemez, Arif Orçun \& Server Demirci, (2013), “The Nonlinear Causality Between the International Capital Flows and Economic Growth in Turkey", Finansal Araştırmalar ve Çalışmalar Dergisi, 8.

Spahn, P. Bernd, (1996), "The Tobin Tax and Exchange Rate Stability", Finance and Development, ss.24-27.

Tax the World: EU's Controversial Tobin Tax Might Take Effect in 2014, www.rt.com/business/eu-transactions-tax-agreed-2014-292/, Erişim: 29 Mart 2013.

Tobin, James, (1978) “A Proposal For International Monetary Reform”, Eastern Economic Journal, ss.153-59.

Whetley, Jonathan, "Brazil Imposes Tax on Foreign Investments", Financial Times Europe Edition, 20 Ekim 2013. 
White, William R., "Making Macroprudential Concerns Operational", Speech at a Financial Stability Symposium organized by the Netherlands Bank, Amsterdam, 25-26 October 2004. http://www.bis.org/speeches/sp041026.htm, Erişim: 14 Mart 2013.

World Trade Organization (2011), "World Trade Report 2011: the WTO and preferential trade agreements: from co-existence to coherence". http://www.wto.org/english/res_e/ booksp_e/anrep_e/world_trade_report11_e.pdf, Erişim 21 Mart 2013. 